\title{
Time trends in the use and appropriateness of natriuretic peptide testing in primary care: an observational study
}

Mark Valk1* Arno W Hoes ${ }^{1}$, Arend Mosterd ${ }^{1,2}$ Brenda Broekhuizen ${ }^{1}$ Nicolaas Zuithoff', Frans H Rutten ${ }^{1}$

${ }^{1}$ Julius Center for Health Sciences and Primary Care, University Medical Center Utrecht, Utrecht, The Netherlands; ${ }^{2}$ Department of Cardiology, Meander Medical Center, The Netherlands, Amersfoort
*For correspondence: $\mathrm{m}$.j.m. valk-7@umcutrecht.nl

Competing interest: The authors declare that no competing interests exist.

Received: 26 November 2019 Accepted: 06 January 2020

Published: 12 August 2020

@This article is Open Access: CC BY license (https://creativecommons.org/licenses/by/4.0/)

Author Keywords: Heart failure, primary care, natriuretic peptides, time trend, diagnosis

Copyright (C) 2020, The Authors; DOI:10.3399/

bjgpopen20X101074

\begin{abstract}
Background: Diagnosing heart failure (HF) is difficult, relying on medical history, symptoms, and signs only. Clinical guidelines recommend natriuretic peptides (NPs) as an additional diagnostic test, notably to exclude HF in suspected patients. NP testing has been available since 2003 for primary care in the Netherlands, but little is known about its uptake.
\end{abstract}

Aim: To evaluate the trend in ordering and appropriateness of NP testing in primary care.

Design \& setting: An observational study was performed between January 2005 and December 2013. Nine Dutch general practices participated, with 21000 registered people (approximately 4300 aged $\geq 65$ years).

Method: The total number of patients undergoing NP testing each year was calculated per 1000 patient years (PY) based on the total practice population. NP levels were used to assess whether NP testing was applied to exclude or confirm HF.

Results: The number of NP testing increased from 2.5 per 1000 PY in 2005 to 14.0 per 1000 PY in 2013, with a peak in 2009 of 15.6 per 1000 PY. The proportion of participants with $\mathrm{N}$-terminal B-type natriuretic peptide (NTproBNP) below $125 \mathrm{pg} / \mathrm{ml}$ (the exclusionary threshold recommended by the European Society of Cardiology [ESC] guidelines on HF) was on average $30 \%$, and highest in the first year (47\%).

Conclusion: After a rapid uptake of NP testing in primary care from 2005 onwards, the use of it seemed to stabilise after 2009, thus leaving patients who are prone to HF without an optimal diagnostic workup.

\section{How this fits in}

Diagnosing HF is difficult when only relying on medical history, symptoms, and signs. Guidelines recommend NP as an additional test in suspected patients. The use of NP testing for exclusion of HF diagnosis and opportunistic screening should be considered by GPs more often. After a rapid uptake of NP testing in primary care from 2005 onwards to 2009 it stabilised, although there is room for improvement.

\section{Introduction}

$\mathrm{HF}$ is an important health problem, and adequate management starts with a correct diagnosis. However, when relying on medical history, symptoms, and signs only, diagnosing HF is notoriously 
difficult. ${ }^{1,2}$ Electrocardiography provides relevant information, but is not generally available in general practice, and access to echocardiography is even more limited. In clinical guidelines, NPs, notably B-type (BNP) and amino-terminal B-type (NTproBNP) are recommended for the initial diagnostic assessment of patients suspected of HF immediately following history taking, signs, and symptoms, to exclude $\mathrm{HF}$ and select those requiring echocardiography to confirm the diagnosis. ${ }^{3}$

NPs were first identified in the porcine brain in $1988 .{ }^{4}$ Measurement of NP levels in patients became available in hospital laboratories around 2002, and in 2003 Dutch GPs could order this testing in laboratories. In 2005, the Dutch primary care guideline on HF recommended for the first time BNP or NTproBNP testing for the initial diagnostic assessment of patients with symptoms and signs suggestive of HF in the primary care setting. ${ }^{5}$ The updated 2010 Dutch primary care HF guidelines, ${ }^{6}$ and also the 2012 and 2016 ESC guidelines on $\mathrm{HF}^{3,7}$ specifically mentioned the importance of NP testing (and electrocardiography) as a means to exclude the presence of non-acute HF (very high negative predictive value), and, therefore, recommended a very low exclusionary cut-point (NTproBNP $<125 \mathrm{pg} / \mathrm{ml}$, BNP $<35 \mathrm{pg} / \mathrm{ml}$ ) below which other diagnoses than HF should be considered, and above which patients should be referred for echocardiography. ${ }^{3,7}$ The National Institute for Health and Care Excellence (NICE) guidelines on HF, however, based their NTproBNP cut-point $400 \mathrm{pg} / \mathrm{ml}$ on the best accuracy of this test (optimal balance sensitivity and specificity). ${ }^{8}$ At that cut-point fewer patients will be referred for echocardiography and, in those referred HF, will be detected more often but at the price of missing patients with HF, notably those with preserved ejection fraction with NTproBNP values below $400 \mathrm{pg} / \mathrm{ml}$. Recent studies clearly demonstrated on the one hand that many $(40 \%-80 \%$ in some high-risk groups) older patients with HF in primary care have not been recognised as such

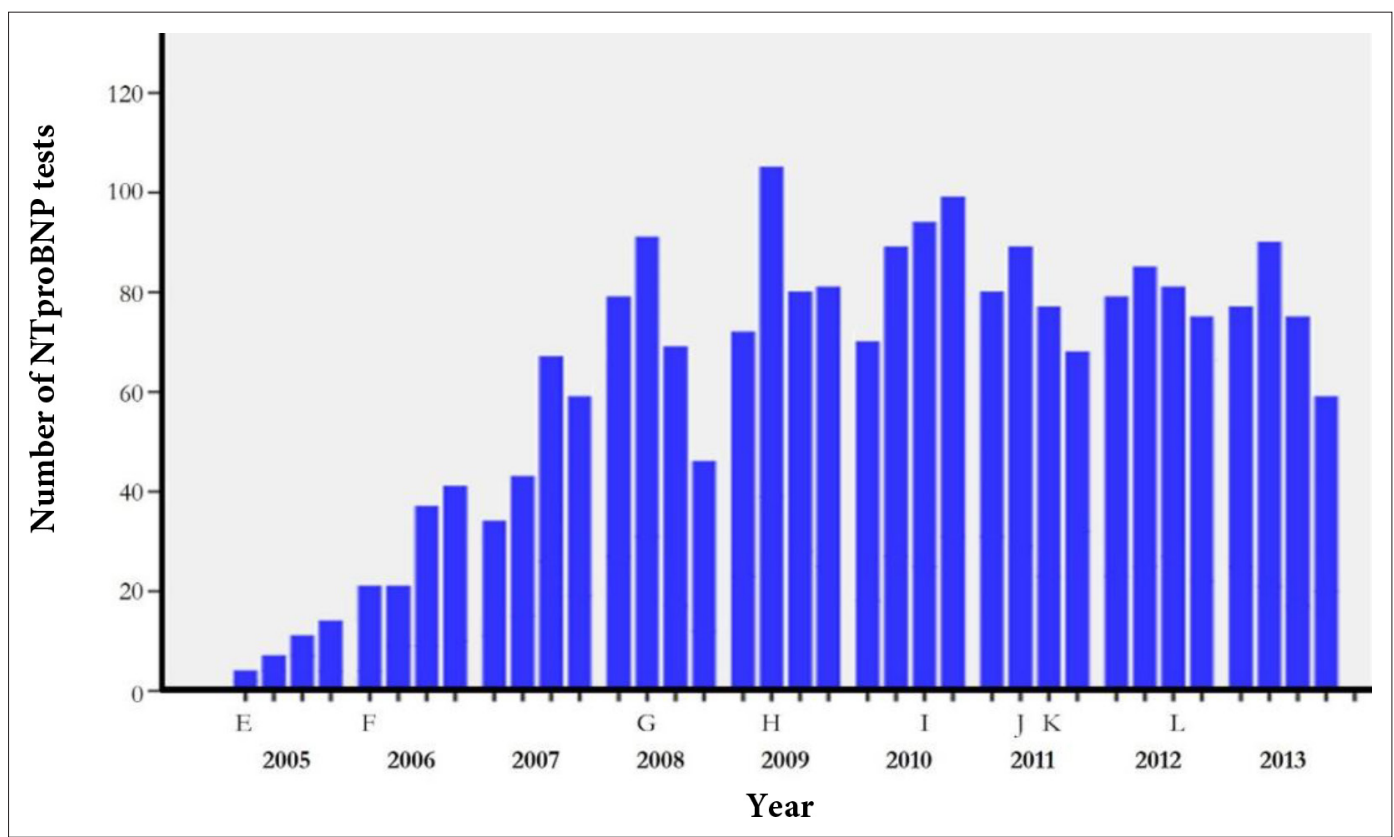

Figure 1 Number of N-terminal B-type natriuretic peptide (NTproBNP) tests as was ordered per quarter of the year by GPs in the period January 2005 until December 2013.

The letters E to L correspond to the following events: (E) 2005: Update of the Dutch GPs' guidelines on heart failure (HF), now mentioning NTproBNP and BNP as an option in the diagnostic assessment. Also in this year an update of the European Society of Cardiology (ESC) guidelines on HF. (F) 2006: Patient reimbursement stopped for laboratory testing. (G) 2008: Update of the ESC guidelines on HF, clearly recommending natriuretic peptides (NPs) for diagnosis, but without advocating a cut-point. (H) 2009: Single-day training on the diagnosis of HF and the use of NTproBNP of the participating GPs of Soest. (I) 2010: Update of the Dutch GPs' guidelines on HF, now recommending the use of the NTproBNP exclusionary cut-point of $125 \mathrm{pg} / \mathrm{ml}$ (approximately $15 \mathrm{mmol} / \mathrm{l}$ ). If values are below this threshold, and the electrocardiogram is normal, than HF is very unlikely and other diagnoses should be considered to explain the symptoms of patients. (J) 2011: Regional agreement on open-access echocardiography in the Soest area. (K) 2011: Regional agreement between GPs and cardiologists on HF referral, diagnosis, and management in the Soest area. (L) 2012: Update of the ESC guidelines on HF, now also explicitly recommending the exclusionary cut-point of $125 \mathrm{pg} / \mathrm{ml}$ (approximately $15 \mathrm{mmol} / \mathrm{l}$ ) for NTproBNP 
(underdiagnosis), ${ }^{9-12}$ while on the other hand patients with a GP's label of HF in $17 \%$ did not really have $\mathrm{HF}$, according to an expert panel using all available diagnostic information (overdiagnosis). ${ }^{13}$ Around $30 \%$ of patients suspected of HF by the GP and referred to a cardiologist actually have HF based on a full diagnostic work-up (including echocardiography). ${ }^{2,14}$

Currently, there is very limited data on the uptake of NP testing in primary care over time. Against this background, the study investigated the time trend in ordering NP testing by GPs in the Netherlands from 2005 to 2013.

\section{Method}

GPs from nine primary care practices in Soest, a city in the vicinity of Utrecht, the Netherlands, participated in the study between March 2005 and December 2013. In the Netherlands, all inhabitants are registered with a GP, irrespective of cooperative care of a hospital specialist, except for patients living in a nursing home or hospice. In the participating practices, 21000 individuals were enlisted (approximately 4300 aged $\geq 65$ years). All patient contacts and specialist letters were kept by the GP in an electronic medical record (EMR).

All NP measurements ordered by the participating GPs between January 2005 and December 2013 were extracted from the Meander Medical Center hospital database. In this region, NP ordering became available for GPs in 2003, with the hospital laboratory of Meander Medical Center as the regional supplier. This laboratory used NTproBNP, and it was measured on the Elecsys analyser (Roche

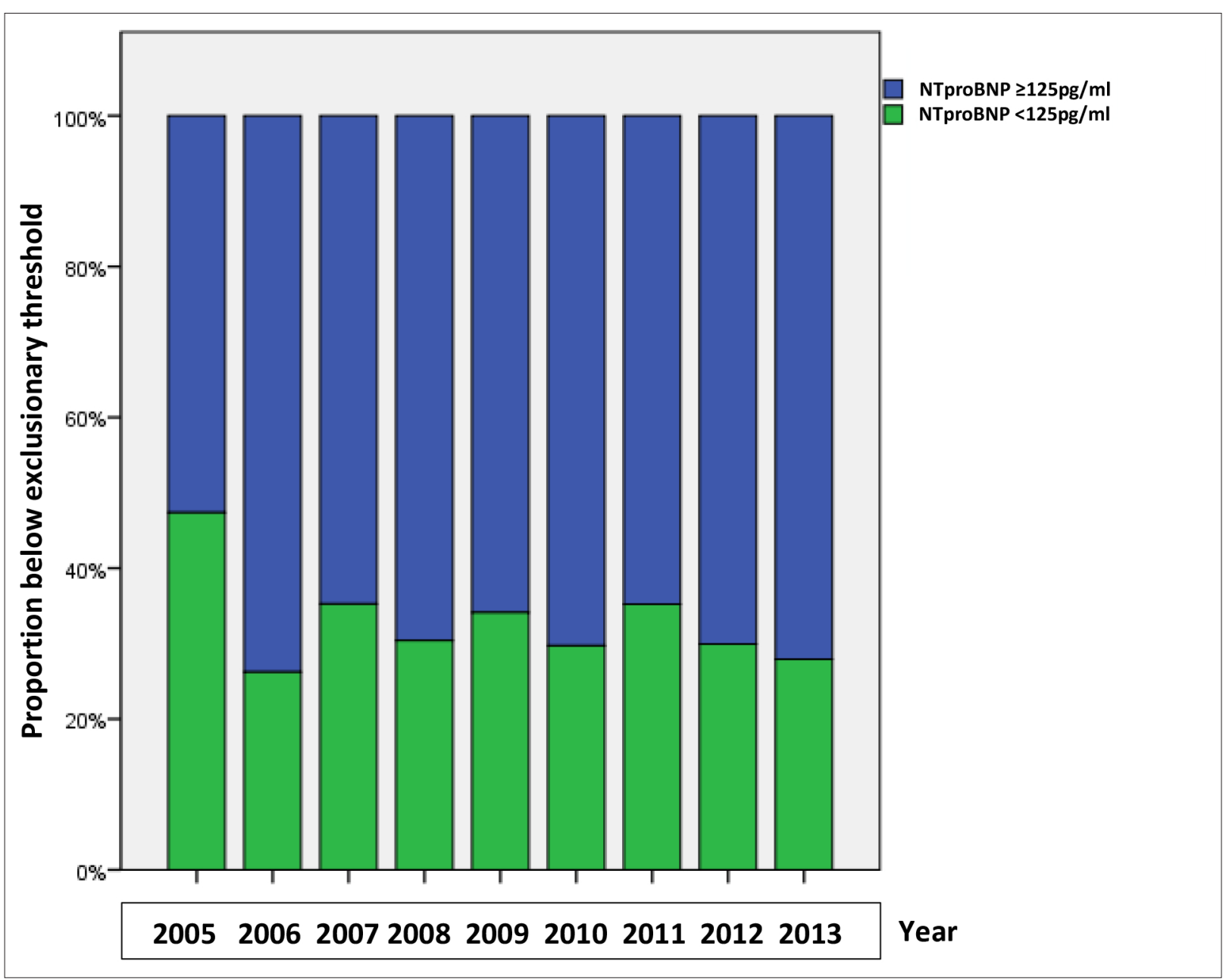

Figure 2 Proportion of the participating GPs ordered NTproBNP values above and below the exclusionary threshold of $125 \mathrm{pg} / \mathrm{ml}$ for each year from 2005-2013 
Diagnostics). Results were given in pg/ml. In Figure 1 events between 2005 and 2013 are summarised that may have affected the ordering of NTproBNP tests.

The total number of enlisted people and the proportion aged $\geq 65$ years were calculated for each year.

The participating GPs agreed to the use of de-identified patient data, and signed informed consent. The study was conducted in accordance with the Law for the Protection of Personal Data and confirmed to the principles outlined in the Declaration of Helsinki. ${ }^{6,14,15}$

\section{Data analysis}

The number of NTproBNP tests ordered was calculated per 1000 PY for each year between 2005 and 2013. NTproBNP values were dichotomised at $125 \mathrm{pg} / \mathrm{ml}$ (approximately $15 \mathrm{mmol} / \mathrm{l}$ ) to determine the proportion of tests that likely served to exclude HF.

\section{Results}

During the 9-year period, 2269 NTproBNP measurements were ordered by the participating GPs; in 2005, 2.5 orders per 1000 PY, increasing in subsequent years to 15.6 orders per 1000 PY in 2009, with stabilisation afterwards. At the end of the study period in 2013, 14.0 tests were ordered per 1000 PY (Figure 1).

The proportion of NTproBNP results below $125 \mathrm{pg} / \mathrm{ml}$ was on average $30 \%$ during the study period. The highest was in 2005 with $47 \%$ followed by a decline in 2006 to $26 \%$, and remaining the following years in the range 28\%-35\% until the end of the study in 2015 (Figure 2).

\section{Discussion}

\section{Summary}

NP testing by Dutch GPs increased steeply from 2.5 per 1000 PY in 2005 to 15.6 per 1000 PY in 2009, followed by a stabilisation in the subsequent years (14.0 per 1000 PY in 2013). The availability of Btype NPs and guideline recommendations for their use in the diagnostic assessment seems to have contributed to the increase in NP ordering by GPs (see Figure 1). The peak in 2009 may additionally be related to the 1-day training on diagnosing and treating $\mathrm{HF}$, as was provided to the participating GPs in that year.

\section{Strength and limitations}

The strength of the study was that all participating GPs sent their requests to one single hospital laboratory. A limitation was that the individual patient data could not be assessed. Patient characteristics could, therefore, not be provided nor exclusions made when GPs ordered multiple NP measurements over time, in some cases for monitoring. Such monitoring, however, is certainly not common practice in Dutch primary care.

\section{Comparison with existing literature}

To the best of the authors' knowledge, there are no other studies published in international medical journals about time trends in NP testing in primary care. A small study on time trends was published in a Dutch medical journal providing data over the period 2004-2007, also showing an increase in NP testing, from 1.0 per $1000 \mathrm{PY}$ in 2004 to 6.5 in $2007 .{ }^{16}$

In the present study, on average $30 \%$ had NTproBNP values below $125 \mathrm{pg} / \mathrm{ml}$, and that is similar to two other studies in primary care patients suspected of HF published in $2005: 42 \%$ and $24 \% .{ }^{14,17}$ In the latter study, however, only patients with a reduced left ventricular ejection fraction were considered, not those with HF and a preserved ejection fraction (HFpEF). In patients with HFpEF, lower NTproBNP levels can be expected than in those with HF with reduced ejection fraction (HFrEF). 7,14,18

It is known that a minority (around 30\%) of patients who are referred by their GP because of suspected HF based on medical history, symptoms, and signs actually have HF. ${ }^{2,14}$ Conditions other than HF but related to shortness of breath may also result in NTproBNP levels above $125 \mathrm{pg} / \mathrm{ml}$; for example, atrial fibrillation, renal dysfunction, left ventricular hypertrophy, and age $>75$ years. $^{3}$ 
Thus, there seems to be room for improvement of the efficiency of NP testing in primary care. In addition, opportunistic screening should be considered in people with an increased risk of HF; for example, older people from the community with type 2 diabetes, chronic obstructive pulmonary disease (COPD), or those who visit the practice for shortness of breath, or have multimorbidity and polypharmacy. ${ }^{9-12}$

\section{Implications for practice}

Indirectly, the data suggest that GPs do not optimally use NP measurements. This readily available test could be considered in anybody suspected of HF, but also as an opportunistic screening tool in those aged $>60-65$ years with COPD or type two diabetes.

NP testing by Dutch GPs increased steeply from 2005-2009, with a stabilisation from that time onwards. The use of NP testing for exclusion of HF diagnosis and opportunistic screening should be considered more often by GPs.

\section{Funding}

This research received no specific grant from any funding agency in the public, commercial, or notfor-profit sectors.

\section{Ethical approval}

The Medical Research Ethics Committees United (MEC-U) of the Meander Medical Center, The Netherlands, approved the study protocol and the use of de-identified data.

\section{Provenance}

Freely submitted; externally peer reviewed.

\section{Acknowledgements}

Data were provided by Leo Jacobs, specialist laboratory medicine Meander MC, Amersfoort, the Netherlands. The authors thank the participating GPs who contributed to the study: Rudi von Bartheld, Barbara Dongen, Nienke van Olden-Heeringa, Jacqueline van der Geest, Leo Weusten, Mirjam de Haan, Piet Mout, Hans Tiems, Eric Oudshoorn, Monique Smits-Schaffels, and Koen Vrijmoet.

\section{References}

1. Kelder JC, Rutten FH, Hoes AW. Clinically relevant diagnostic research in primary care: the example of B-type natriuretic peptides in the detection of heart failure. Fam Pract 2009; 26(1): 69-74. DOI: https://doi.org/10.1093/ fampra/cmn096

2. Kelder JC, Cramer MJ, van Wijngaarden J, et al. The diagnostic value of physical examination and additional testing in primary care patients with suspected heart failure. Circulation 2011; 124(25): 2865-2873. DOI: https:// doi.org/10.1161/CIRCULATIONAHA.111.019216

3. Ponikowski P, Voors AA, Anker SD, et al. 2016 ESC guidelines for the diagnosis and treatment of acute and chronic heart failure: the task force for the diagnosis and treatment of acute and chronic heart failure of the European Society of cardiology (ESC). developed with the special contribution of the Heart Failure Association (HFA) of the ESC. Eur J Heart Fail 2016; 37(27): 2129-2200. DOI: https://doi.org/10.1002/ejhf.592

4. Sudoh T, Kangawa K, Minamino N, et al. A new natriuretic peptide in porcine brain. Nature 1988; 332(6159): 78-81. DOI: https://doi.org/10.1038/332078a0

5. Rutten FH, Walma EP, Ktuizinga Gl, et al. [The Dutch College of General Practiotioners guideline on heart failure, first revision] NHG-Standaard Hartfalen. De standaard en de wetenschappelijke verantwoording zijn herzien ten opzichte van de vorige versie. Eerste herziening (in Dutch). Huisarts Wet 2009; 48(2): 64-76.

6. Hoes AW, Voors AA, Rutten FH, et al. The Dutch College of General Practitioners guideline on heart failure, second revision (in Dutch). Huisarts Wet 2010; 53: 368-389.

7. McMurray JJV, Adamopoulos S, Anker SD, et al. ESC guidelines for the diagnosis and treatment of acute and chronic heart failure 2012: the task force for the diagnosis and treatment of acute and chronic heart failure 2012 of the European Society of Cardiology. Developed in collaboration with the Heart Failure Association (HFA) of the ESC. Eur J Heart Fail 2012; 14(8): 803-869. DOI: https://doi.org/10.1093/eurjhf/hfs105

8. National Institute for Health and Care Excellence. Chronic heart failure in adults: diagnosis and management. 2018; https://www.nice.org.uk/guidance/ng106/resources/chronic-heart-failure-in-adults-diagnosis-and-management-pdf66141541311685 (accessed 10 Jun 2020).

9. Boonman-de Winter LJM, Rutten FH, Cramer MJM, et al. High prevalence of previously unknown heart failure and left ventricular dysfunction in patients with type 2 diabetes. Diabetologia 2012; 55(8): 2154-2162. DOI: https://doi. org/10.1007/s00125-012-2579-0 
10. Rutten FH, Cramer M-JM, Grobbee DE, et al. Unrecognized heart failure in elderly patients with stable chronic obstructive pulmonary disease. Eur Heart J 2005; 26(18): 1887-1894. DOI: https://doi.org/10.1093/eurheartj/ ehi291

11. van Mourik Y, Bertens LCM, Cramer MJM, et al. Unrecognized heart failure and chronic obstructive pulmonary disease (COPD) in frail elderly detected through a near-home targeted screening strategy. J Am Board Fam Med 2014; 27(6): 811-821. DOI: https://doi.org/10.3122/jabfm.2014.06.140045

12. van Riet EES, Hoes AW, Limburg A, et al. Prevalence of unrecognized heart failure in older persons with shortness of breath on exertion. Eur J Heart Fail 2014; 16(7): 772-777. DOI: https://doi.org/10.1002/ejhf.110

13. Valk MJ, Mosterd A, Broekhuizen BD, et al. Overdiagnosis of heart failure in primary care: a cross-sectional study. $\mathrm{Br}$ J Gen Pract 2016; 66(649): e587-e592. DOI: https://doi.org/10.3399/bjgp16X685705

14. Zaphiriou A, Robb S, Murray-Thomas T, et al. The diagnostic accuracy of plasma BNP and NTproBNP in patients referred from primary care with suspected heart failure: results of the UK natriuretic peptide study. Eur $J$ Heart Fail 2005; 7(4): 537-541. DOI: https://doi.org/10.1016/j.ejheart.2005.01.022

15. World Medical Association Declaration of Helsinki. Ethical principles for medical research involving human subjects. JAMA 2013; 310(20): 2191-2194.

16. Oosterhuis W, Boonmans L, Frericks A, et al. [Measurement of N-terminal Pro-BNP in heart failure: from the Dutch College of General Practitioners guideline to daily practice] Bepaling van N-terminaal pro-BNP bij hartfalen: van NHG-standaard naar praktijk (in Dutch). Huisarts Wet 2009; 9: https://www.henw.org/artikelen/bepaling-van-nterminaal-pro-bnp-bij-hartfalen-van-nhg-standaard-naar-praktijk: 434: 438.

17. Gustafsson F, Steensgaard-Hansen F, Badskjaer J, et al. Diagnostic and prognostic performance of N-terminal proBNP in primary care patients with suspected heart failure. J Card Fail 2005; 11(5 Suppl): S15-S20. DOI: https:// doi.org/10.1016/j.cardfail.2005.04.022

18. Taylor CJ, Roalfe AK, lles R, et al. Primary care referral for echocardiogram (refer) in heart failure: a diagnostic accuracy study. Br J Gen Pract 2017; 67(655): e94-e102. DOI: https://doi.org/10.3399/bjgp16X688393 